Martin van Bruinessen,

'Indonesian Muslims and Their Place in the Larger World of Islam',

Paper presented at the $29^{\text {th }}$ Indonesia Update conference, Australian National

University, Canberra, September 30 - October 2, 2011. 


\section{Indonesian Muslims and Their Place in the Larger World of Islam}

Martin van Bruinessen*

With over 220 million Muslims, Indonesia has the largest community of Muslims in the world. Nevertheless, Indonesian Muslims do not play a role in global Muslim thought and action that is commensurate with their numbers. Indonesian Muslims have been eager to learn from Arab as well as Indian, Turkish and Persian thinkers, but do not seem to think they may have something valuable to offer in return. In Indonesian bookshops one finds the translated works of classical and modern Arabic authors, as well as studies of and by major Indian, Pakistani, Iranian and Turkish authors. But Malaysia is the only other country where one can find works by Indonesian Muslim authors, and there are virtually no serious studies of Indonesian Islam by scholars of other Muslim nations. The Arab world has shown a remarkable lack of interest in Asia in general, let alone in the social and cultural forms of Islam in Southeast Asia. ${ }^{1}$ Though more outward looking, other Muslim regions of Asia have not taken a serious interest in their Southeast Asian co-religionists either. ${ }^{2}$

Indonesians are pursuing Islamic studies in India, Pakistan, Iran and Turkey, as well as in the Arab world and in the West. Indian and Turkish Muslims travelling to Indonesia, on the other hand, are not going there as students but as teachers and missionaries. Missionary movements such as the Ahmadiyya and the Tablighi Jama' at (both originating in India) and the Nur and Gülen movements (which started in Turkey) are active all over the world, as are the various

* The author wishes to thank Martin Slama, Ulil Abshar-Abdalla, Mona Abaza and Tony Reid for their comments on an earlier version of this paper.

${ }^{1}$ The sole Egyptian academic to have published serious studies on Malaysian and Indonesian Islam, as well as on the relationship between the Middle East and Indonesia, is the Germantrained sociologist Mona Abaza. Her overview of Arabic writing on Asia reveals how shallow and uninformative most of the existing literature is (Abaza 2011; see also Abaza 2007). She makes an exception for an encyclopaedic work on Islam among non-Arabic speakers by Ahmad Shalabi (1983), who spent many years teaching in Indonesia in the 1950s and 1960s.

2 One exception is Göksoy's (1995) work on Islam in Indonesia under the Dutch. Originally a dissertation submitted to the School of Oriental and African Studies in London, the book was later published in Turkish by a publishing house associated with Turkey's Directorate of Religious Affairs. 
transnational movements originating in the Arab world. But no corresponding Indonesian movement is attempting to spread its message beyond the confines of the country.

The apparent lack of interest in Indonesia as a great Muslim nation, and the reluctance of Indonesian Muslims to make their religious culture better known in the wider world, calls for an explanation. Indonesian Islam has a number of traits that have struck outside observers as unique and even enviable. One such observer was the late Pakistani-American scholar Fazlur Rahman (d. 1988). He was the intellectual mentor of a number of prominent young Indonesian intellectuals, most notably Nurcholish Madjid and Syafi'i Ma'arif. His rationalistic and analytical approach caused him problems in Pakistan but seemed to appeal to many Indonesians, and he was invited there several times. He liked what he saw in Indonesia, and certainly did not consider Indonesian Islam to be inferior or less authentic than Arab or Indian Islam.

Fazlur Rahman made friendly comments about Pancasila as an Indonesian exegesis (tafsir) of Islam that was suited to Indonesian society and culture. ${ }^{3}$ The Pancasila state, he said, provided precisely the climate of religious tolerance that would enable free development of religious thought. He was very pessimistic about the state of intellectual debate in the Muslim world in general but saw two exceptions that gave reason for hope: Indonesia and Turkey. He was convinced that if there was to be a renaissance of the Muslim intellectual tradition, it would begin in those countries. ${ }^{4}$ Another critical reformist scholar of Islam was the Egyptian Nasr Hamid Abu Zayd (d. 2010). Like Fazlur Rahman he had to leave his country of birth and spend his last years in exile, but he too found dedicated groups of admirers in Indonesia and Turkey and regularly visited both countries.

This raises again the question of the relative invisibility of Indonesian Islam. If it is the case that Turkey and Indonesia share certain conditions that allow or even stimulate the development of an original and daring Muslim intellectual discourse, why is it that we see Turkey and Turkish Muslim movements projecting themselves confidently in the wider world whereas Indonesia and Indonesian Muslims do not? Is it just a matter of modesty or lack of confidence, or are other factors at play?

\footnotetext{
${ }^{3}$ The Pancasila are the five guiding principles of the Indonesian state, namely belief in God, humanitarianism, national unity, democracy and social justice.

${ }^{4}$ Conversations with Fazlur Rahman, Jakarta, 15-17 August 1985.
} 


\section{IS INDONESIAN LEADERSHIP IN THE MUSLIM WORLD THINKABLE?}

There was a time when Indonesian Muslims felt more confident about their role in the world, and other Muslims, even in the Middle East, appeared to notice something worth emulating in them. Allow me to reconstruct from memory a conversation I had in the late 1980s with Kiai Abdullah Abbas, the head of the large pesantren of Buntet near Cirebon. ${ }^{5}$ He was one of the most prominent members of Nahdlatul Ulama (NU) in West Java, and one of Abdurrahman Wahid's staunchest (and most crucial) supporters. ${ }^{6}$ A man of broad views and rich experience, he enjoyed sharing his memories of the closing years of Dutch colonial rule, the Japanese occupation, the struggle for independence and stormy years of the young republic, the violent inauguration of the New Order and the years of development under Suharto. The best years, the period when he felt most alive, were apparently the Sukarno years:

We are more prosperous now, but in those days we were proud of being Indonesian. When we went to Arabia on the hajj and told people where we were from, they always responded positively. They would say, 'Ah! Indonesia! Ahmad Sukarno!' and give us a thumbs-up. We felt that we counted for something in the world. Nowadays we don't get that sort of response any more when we travel abroad; something important has been lost ...

Kiai Abdullah admittedly was a Sukarnoist and Indonesian nationalist, and one of those who felt that Indonesia, as a large Muslim nation recently liberated from the colonial past, should rightly play a leading role in a third bloc between the capitalist (and largely Christian) bloc and the communist (and presumably atheist) bloc. The Bandung Conference (1955) and succeeding conferences confirmed Sukarno's - and by implication Indonesia's - leading role in the ensuing Non-Aligned Movement (Mackie 2005). By performing the pilgrimage to Mecca (in 1955) and adopting the name 'Ahmad', Ir. H. Ahmad Sukarno emphasized his identity as a Muslim leader and as a leader of Muslims. Kiai Abdullah's nostalgic memories

\footnotetext{
${ }^{5}$ A pesantren is a traditional Islamic boarding school. The religious scholar or leader in charge of the pesantren is called a kiai.

${ }^{6}$ Abdurrahman Wahid was the head of NU from 1984 to 1998 and the president of Indonesia from 1999 to 2001.

${ }^{7}$ Conversations with K.H. Abdullah Abbas, Pesantren Buntet, Cirebon, 10-11 October 1987.
} 
suggest that many Muslims of other nations recognized Indonesia's leading role and shared the hopes of a shift in the global balance of power.

Half a century ago, the idea of the secular Muslim nation of Indonesia leading what came to be known as the Third World was not only thinkable but briefly appeared to become a reality. As we know now, the dream was not to last: the Non-Aligned Movement fell apart, Sukarno was brought down, and under Suharto Indonesia renounced its revolutionary vanguard role. Since the demise of the New Order in 1998, there have been a few attempts to raise Indonesia's international profile as a leading Muslim nation (about which more below) but so far these have not been very successful. Indonesia's visibility has increased and its significance is being recognized, but it is not (or not yet?) a country that others look to for leadership.

Indonesian leadership in international organizations has not been entirely absent in the postSukarno period, however. The most prominent example is Mohamad Natsir, a former head of Masyumi (the largest political party in Indonesia in the late 1940s and 1950s), prime minister from 1950 to 1951, and a staunch critic of Sukarno's who spent the last years of the latter's rule in jail and was still not allowed to return to formal politics under Suharto. He was given leading positions in various Saudi-sponsored international bodies, notably the Muslim World League (Rabita). The league was established by Saudi Arabia in 1962 to counter the revolutionary influence from Nasser's Egypt, which threatened to undermine the monarchies of the Gulf region. Ideologically it was at the opposite end of the political spectrum from the Non-Aligned Movement. Natsir, a product of the puritan reformist Muslim movement Persis, was liked and trusted by the Saudis. He was for many years a member of the "council of founders' of the Muslim World League and a board member of various associated bodies. The organization for Islamic propagation that Natsir founded in 1967, the Indonesian Council for Islamic Propagation (DDII), doubled as the de facto Jakarta office of the Muslim World League as long as Natsir was alive - only after his death in 1993 was a Saudi sent to Jakarta to represent it. ${ }^{8}$

Natsir obviously owed his position not only to his personal qualities but to the perceived demographic importance of Indonesian Islam. He never used the position to draw attention to

\footnotetext{
${ }^{8}$ Natsir appears in various roles in a major study of the Muslim World League by Schulze (1990). See also Schulze (1983).
} 
specifically Indonesian Muslim thought or cultural expressions, which probably had no religious legitimacy for him. ${ }^{9}$ Indeed, in an early debate on Indonesia's national culture pitting nativists against Westernizers in the 1930s, Natsir contributed a booklet on 'Muslim culture' in which he spoke exclusively of the golden age of Muslim civilization in the Middle East and made no reference at all to any Indonesian contribution. ${ }^{10}$

It was through Natsir and DDII that Islamist and later Salafi ideas spread from the Arabian peninsula to Indonesia, carried by young Indonesians selected for study in Saudi Arabia. ${ }^{11}$ Natsir was influential, but his influence largely remained restricted to getting the Saudi authorities to pressure Indonesia to adopt domestic policies that conformed to Saudi perceptions of the furtherance of Islamic interests. He kept his prominent position in the Muslim World League until the late 1980s, when the Suharto regime successfully lobbied the Saudis for him to be replaced by a more pliable figure, H.M. Rasjidi.

Even in the heyday of Indonesia's leading role in the Non-Aligned Movement, the respect accorded Indonesian Muslims by fellow believers of other nationalities reflected the country's political role in the world and appears not to have been translated into interest in, let alone appreciation of, Indonesian Muslim culture(s) and learning. Foreign Muslims who came to study in Indonesian pesantren were typically from other parts of Southeast Asia (Malaysia, Thailand, Cambodia) and rarely if ever from South Asia, the Middle East or Africa.

Indonesians seeking advanced knowledge of Islam, on the other hand, would spend years in madrasah in Mecca, at Al-Azhar University in Cairo or occasionally in India or Pakistan. ${ }^{12}$ Religious scholars (ulama) from those places also travelled to Indonesia as teachers, but only very rarely were learned Indonesians invited to teach in the Middle East.

\footnotetext{
${ }^{9}$ However, an anonymous book on the political position of Muslims in New Order Indonesia and Christian conspiracies to undermine Islam in the archipelago is commonly attributed to him; see Al-Andunisi (1984).

${ }^{10}$ See Mujiburrahman (2006: 207-11) for an analysis of the debate, which has become known in retrospect as the Polemic on Culture (Polemik Kebudayaan).

${ }^{11}$ Salafism seeks a return to the teachings and example of the early generations of Muslims; the term usually refers to the most strictly fundamentalist and puritanical stream of Islamic thought.
}

${ }^{12}$ A madrasah - or medrese (see below) - is an Islamic school or college. 
Religious authority is by definition an unequal relationship, and Indonesians were almost always on the receiving end of the relationship. Indonesian Muslims have developed a wide range of unique expressions of Islam, but they have shown no great zeal in propagating them to other parts of the Muslim world.

\section{INDONESIAN ULAMA AND TRANSNATIONAL SCHOLARLY NETWORKS}

The preceding observation about the apparent one-way nature of religious authority and teaching requires qualification. Indonesians studying in Mecca or Cairo often did so under teachers who were, like themselves, of Southeast Asian origin. Linguistic competence in Malay and/or Javanese no doubt played a part in bringing teachers and students together, but we know that some of these teachers did in fact also have non-Southeast Asian students. Azyumardi Azra has drawn attention to the fact that the eighteenth-century scholar from Palembang, Abdussamad al-Jawi (al-Falimbani), who taught for many years in Medina and Yemen, had numerous Arab as well as Malay students (Azra 2004: 112-17). Michael Feener and Michael Laffan (2005) have found references to a much earlier Sufi scholar in Aden with probable Southeast Asian connections who influenced well-known contemporary Arab scholars. ${ }^{13}$

Abdussamad and other Southeast Asian scholars active in Arabia were connected by teacherstudent links and correspondence with numerous other ulama in scholarly networks that spanned the Middle East, Asia and Africa. In such networks, ethnicity and place of origin are almost by definition irrelevant, since the main criterion for membership is the recognition of learning. Southeast Asians who enjoyed peer recognition as accomplished scholars could be chosen as teachers by students of diverse ethnic origins. However, it was residence in Mecca, Medina or Cairo that made it possible for them to become internationally recognized. I do not know of any great scholar permanently based in Indonesia whose name drew students from abroad to his feet. Apart from teaching in the Arabian heartland, writing learned books in Arabic is another possible way of gaining renown and authority in the wider world. All Indonesian authors of major Arabic Islamic texts of whom I am aware, however, were residents of Mecca or Medina and also taught there.

\footnotetext{
${ }^{13}$ Sufism is the mystical dimension of Islam; a Sufi is a Muslim mystic.
} 
Perhaps I may add a minor observation here. While browsing in an Islamic bookstore in Diyarbakir, in Turkish Kurdistan, I came across a book whose author I recognized as Indonesian: Ihsan bin Muhammad Dahlan of Jampes, Kediri (d. 1952). Enthusiastically I showed it to the bookseller, saying: 'This author is an Indonesian, and he is very famous in East Java'. The man was not impressed but politely asked a few things about Indonesia and complimented the Indonesians he had encountered during the hajj on their modest and polite behaviour. He did not think, however, that the author's nationality was relevant to the authority of the book (Dahlan n.d.), a commentary - probably the most recent of many - on a well-known eleventh-century Sufi text by Ghazali. The discursive world of commentaries, supercommentaries and glosses on classical texts that constitute the main material of study in traditional madrasah all over the world is largely deterritorialized.

Some of the most prolific Southeast Asian ulama based in Mecca in the late nineteenth century appear to have written their works not as contributions to the global scholarly discourse, but as popularizing summaries and commentaries intended for Southeast Asian audiences. Muhammad bin Umar Nawawi of Banten and Da'ud bin Abdullah of Patani wrote numerous books in Arabic and Malay respectively, which were originally printed in Mecca or Cairo and later reproduced cheaply in such places as Singapore and Surabaya (van Bruinessen 1990; Bradley 2010). This phenomenon underscores the prestige and authority that association with Arabia attaches to books as well as persons in the eyes of ordinary Southeast Asians. No matter how impressive one's lineage or scholarship, one does not become a respected kiai in Java unless one has spent a few years studying in Mecca or, nowadays, Cairo. The process of Islamization of the archipelago over the past six centuries, and of Islamic reform over the past three, has been powered less by foreign preachers and missionaries arriving from abroad than by local people travelling to Arabia in search of knowledge and prestige.

\section{HADRAMAUT AND SOUTHEAST ASIA}

A group of Islamic scholars who have been of special significance for Southeast Asian Islam are the Sayyid (presumed descendants of the Prophet) of Hadrami origin. ${ }^{14}$ Hadrami traders and scholars, Sayyid as well as commoners, have been travelling to Southeast Asia from the Middle East for many centuries. We find such men occasionally mentioned in the seventeenth

\footnotetext{
${ }^{14}$ Hadramaut is a region in South Arabia, in the east of the present state of Yemen.
} 
and eighteenth centuries - Abdussamad al-Jawi of Palembang and the famous Acehnese scholar and mystic Nuruddin Raniri were both of Hadrami descent on the father's side, though born in Sumatra and Gujarat respectively of local women. Hadrami migration to Indonesia increased massively in the nineteenth and twentieth centuries. Some of the men who had made their fortunes in trade with Indonesia later resettled in Hadramaut. As travel became easier, Indonesianized Hadramis also revisited the old country, resulting in increasing cultural exchange between the two regions. ${ }^{15}$

Hadrami society, in Indonesia as well as in Hadramaut itself, was highly stratified, with the Sayyid occupying the upper stratum and carefully maintaining the social boundary separating them from other Hadramis. All commoners (including indigenous Indonesian Muslims) were expected to kiss the hand of a Sayyid when meeting, and whereas Sayyid freely took indigenous women as their wives, they never allowed anyone but another Sayyid to marry their sisters and daughters. Existing tensions between the Sayyid and other Hadramis came to a head in the early twentieth century over a series of conflicts sparked by a reformist teacher originally from Sudan, Ahmad Soorkatti. He arrived in Java in 1911 to teach in the schools of Indonesia's first modern Muslim association, Jamiat Khair, which was dominated by the Sayyid. He held that all men were equal and that the Sayyid claim to superiority because of their genealogy was spurious. Soon the entire Hadrami community of Java was divided over the issue. The anti-Sayyid faction split from Jamiat Khair, establishing the Muslim reformist association Al-Irsyad, led by Soorkatti; the Sayyid withdrew to a fiercely anti-reformist, mystically tinged traditionalism and cultivation of their families' hereditary charisma. ${ }^{16}$

Natalie Mobini-Kesheh (1999) has described how the conflict between the two groups, which was fought out with theological arguments, was transplanted from Java back to Hadramaut, where it again led to challenges to the dominant position of the Sayyid (see also Kostiner 1984). This is the only major case of which I am aware where a development in Indonesian Islam had an impact in the Middle East. The conflict hardly affected indigenous Indonesians,

\footnotetext{
${ }^{15}$ In recent years there has been considerable academic interest in the Hadrami diaspora and its relations with the homeland, resulting in several important publications. A particularly insightful study is Ho (2006).

${ }^{16}$ On the complex stratification of Hadrami society, see Heiss and Slama (2010). On Soorkatti’s interventions, see Pijper (1977: 109-20) and Mobini-Kesheh (1999).
} 
however; by and large, membership of Al-Irsyad has remained restricted to Indonesian Arabs. It is therefore more appropriate to speak of a conflict in the Hadrami diaspora having an impact on power struggles in the homeland. Conditions in Indonesia were at best a catalyst for the conflict - no Indonesians were directly involved.

\section{THE SINGULARITY OF INDONESIA'S ISLAMIC ORGANIZATIONS}

Indonesian Islam can boast a number of unusual features that have drawn the admiration of foreign Muslim observers. The pattern of associational life is one of them. Indonesianists may take the existence of the largest associations - the modernist Muhammadiyah and the traditionalist NU - for granted, because they have been there so long (since 1912 and 1926 respectively) and appear to be such an inevitable part of the societal landscape. But nowhere else in the Muslim world do we find anything quite like them. ${ }^{17}$ Both have various affiliated unions and institutions (women's, youth and students' associations, and a wide range of NGOs) and are organized at the national, provincial and district levels, with elected boards at each level. Their five-yearly congresses, where new leaders are elected and general policies established, are massive exercises in democratic decision making. Heavy-handed government intervention in these congresses has been the rule rather than the exception, especially under Suharto, but the organizations have always shown considerable resilience and maintained a degree of autonomy.

Muhammadiyah has established thousands of schools and dozens of universities, hospitals and orphanages in most major cities, and even a few banks, all of them run by a wellorganized bureaucracy. NU is less professionally organized, reflecting the different social backgrounds of its membership; it represents the world of the pesantren, a broad segment of the rural masses and small-town business people. It does not control the pesantren, as Muhammadiyah controls its schools - the kiai tend to guard their independence and are extremely wary of external intervention in their schools - but functions as a forum for communication and mutual consultation, and in various ways represents the interests of its constituency.

${ }^{17}$ The Muslim Brotherhood, which was established in Egypt in 1928 and later spread to other Arab countries, has never attained the same level of organization, transparency or societal penetration, though it developed more systematic methods of disciplining its cadres. 
Muhammadiyah and NU enjoy strong legitimacy as representatives of broad segments of the Islamic community (ummah), and they have remained the largest and strongest embodiments of civil society throughout the twentieth century. Surveys show that their members tend to be more active than average in other societal activities such as neighbourhood associations and charitable work. These associations have arguably been a stabilizing force, helping to enable the democratic transformation of the country.

Though both have their regional centres of gravity, they have long been organized throughout the country and have played an important part in strengthening a common national awareness among Muslims. Like similar but smaller associations such as Persis, Muhammadiyah and NU have never attempted to expand their activities to non-Indonesian Muslim populations; their few foreign branches serve only Indonesian residents abroad. Leaders of the organizations - most conspicuously Abdurrahman Wahid - have been invited to various international conferences, but until recently neither NU nor Muhammadiyah played a leading role on the world stage.

Since the demise of the New Order, both associations have shown increasing confidence and have taken some initiatives to make their mark internationally. Under former chairman Hasyim Muzadi, NU organized the first International Conference of Islamic Scholars in Jakarta, in which prominent ulama from across the world took part. This initiative was not unrelated to Muzadi's personal ambitions - he was Megawati Sukarnoputri's running mate in the 2004 presidential elections, and the first conference conveniently took place in early 2004 - but it also reflected a broadly shared desire to make Indonesia and NU more visible internationally. Megawati delivered an opening speech that appeared to allude to the spirit of the Bandung Conference, calling for cooperation in the face of the great challenges faced by all Muslim nations. Follow-up conferences took place in 2006 and 2008, again with considerable international participation. Muzadi's successor, Said Aqiel Siradj, deliberately broke with many of his predecessor's policies but continued the effort to make NU more internationally prominent by organizing a large meeting of Sufi orders in July 2011.

\section{THE STRENGTH OF LIBERAL AND PROGRESSIVE RELIGIOUS THOUGHT}

Indonesia has produced some remarkable Muslim thinker-activists, men as diverse as Tan Malaka, Haji Misbach, Tjokroaminoto, Agus Salim, Mohamad Natsir, Kartosuwiryo, Nurcholish Madjid, Dawam Rahardjo, Kuntowijoyo and Abdurrahman Wahid. With very few 
exceptions, their writings have not been translated into Arabic or English, and their thinking has therefore never made the impact in other parts of the world that many would judge it deserves. One may adduce a number of possible explanations for this state of affairs, although none of them is entirely satisfactory.

It is doubtless the case that Muslim activists in the Middle East have been more interested in the demographic and political weight of the Indonesian ummah than in its possible contribution to Islamic thought. Besides the general bias towards the Middle East, this may be due to the widespread perception that Indonesian Islam tends to be syncretistic and less than rigorous (which is exactly what many Westerners find attractive about it). But although similar perceptions have long existed concerning Indian Islam, South Asian Muslim thinkers such as Mohammad Iqbal, Abu'l A'la Maududi, Fazlur Rahman and Asghar Ali Engineer have had a major influence beyond their own region.

Another possible explanation is that much Indonesian Muslim writing specifically concerns the Indonesian context and conditions that do not prevail elsewhere, making it less relevant to other nations. Indonesian Muslim thinkers have moreover typically been people of action whose thinking was expressed in the context of, and in a format appropriate to, social and political struggles. Much of their energy went into organizing, teaching, and establishing associations or NGOs. ${ }^{18}$ Their intellectual output took the form of numerous speeches, essays and short articles, and rarely if ever a substantial synthesizing work. An Indonesian Muslim intellectual's book typically consists of a collection of heterogeneous articles, many of them addressing specifically Indonesian concerns. ${ }^{19}$

${ }^{18}$ It is no coincidence that Pramoedya Ananta Toer's famous quartet of novels - based on the life of Tirtoadisoerjo, founder of the first indigenous newspaper and the first Muslim association in the Dutch Indies - emphasizes the importance of organizing as essential to the struggle for liberation, giving it priority even over writing. An anecdote related to me by Ulil Abshar-Abdalla may also be relevant here: an Egyptian visitor to Indonesia jokingly observed that the Qur' an was revealed in Saudi Arabia, is recited in Egypt and is put into practice in Indonesia ('Al-Qur'an nazal fi al-Sa'udiyya, wa yutla fi Masr, wa yu'malu bihi fi Indonesia').

${ }^{19}$ See, for example, Salim (1954), Natsir (1955), Rakhmat (1986), Madjid (1987), Madjid and Roem (2000), Kuntowijoyo (2001) and Wahid (2006). 
This does not detract from the fact that the Islamic discourse developed by the Muslim intellectuals who flourished during the New Order and after - the religious 'renewal' (pembaruan) movement associated with Nurcholish Madjid since 1970 and the various 'liberal' and 'progressive' currents of the 1990s and 2000s - was unique in the Muslim world. I lived in Indonesia myself during much of the 1980s and the early 1990s and regularly attended the public discussions of Muslim intellectuals. The freedom of debate, the courage to think 'out of the box', the intellectual curiosity with which young Indonesian Muslims sought, and acquainted themselves with, ideas beyond the Muslim mainstream and creatively adopted and disseminated them, struck me as highly unusual and unlike anything I knew of elsewhere in the Muslim world. Like other observers, Indonesian as well as foreign, I often wondered with regret why this intellectual creativity, yielding theological arguments in support of interreligious understanding, human rights, democracy, gender equality and greater religious freedom, remained almost unknown and made no impact abroad. ${ }^{20}$

Much of what was most attractive in the ideas of the pembaruan and later liberal and progressive movements was in fact borrowed from thinkers based elsewhere. But it was only in Indonesia (and to some extent Turkey) that the works of these thinkers found a warm reception. The Pakistani Fazlur Rahman, the Indian Asghar Ali Engineer, the Sudanese Mahmoud Muhammad Taha and Abdullahi An-Na'im, the Egyptians Hassan Hanafi and Nasr Abu Zayd, the Moroccan Muhammad Abed al-Jabri - all have found a much wider following in Indonesia than in their own countries. ${ }^{21}$ Indonesia was the only Muslim country to allow the Pakistani-American Muslim feminist theologian, Riffat Hassan, to address students in an Islamic university. ${ }^{22}$ It was also the first country where Abdullahi An-Na'im was able to find

${ }^{20}$ For an overview of the ideas developed in such circles, see van Bruinessen (2011). On the pembaruan movement, see Barton (1995).

${ }^{21}$ Three of them (Rahman, An-Na'im and Abu Zayd) were forced to live in exile; one (Taha) was sentenced to death for his ideas and hanged.

${ }^{22}$ Hassan was invited to Indonesia in 1992 by a small group of women's rights activists and students who had read an article by her published in the Muslim intellectual journal 'Ulumul Qur'an (Hassan 1990). She met mostly with small groups, but was also invited to speak at IAIN Sunan Kalijaga in Yogyakarta, where her talk provoked heated discussion. Hassan's article and her visit were major events in the emergence of an Indonesian Muslim feminism. 
allies to carry out his project to develop a locally grounded Muslim secularist discourse. ${ }^{23}$ Both Hassan and An-Na'im greatly influenced the emerging Indonesian-Muslim feminist movement and Muslim human rights activism, although these movements soon developed well beyond the ideas of their original inspiration.

It was not, then, originality that made Indonesia's liberal and progressive Muslim discourse unique, but its broad degree of acceptance of critical Islamic thought, and perhaps the eagerness with which young Muslim intellectuals sought out foreign authors who could offer interesting ideas that might help them reconstruct Islamic thought. The broad acceptance of such ideas and the widespread participation in relevant debates had much to do with the institutional support for rational analysis provided by the State Islamic Institutes (IAIN), established by the government to train a class of enlightened religious officials. Most of the interesting thinkers were affiliated with the Jakarta or Yogyakarta institutes, where the rectors, Harun Nasution and Mukti Ali, provided protection and an atmosphere of free intellectual debate. ${ }^{24}$

\section{INDONESIA'S MUSLIM WOMEN ACTIVISTS AND ISLAMIC FEMINISM}

Of the various liberal and progressive trends, Indonesia's Muslim feminist movement is the most dynamic and diverse. ${ }^{25}$ It is also the one intellectual trend in Indonesian Islam that has become well known and admired elsewhere in the Muslim world and is gaining some traction there. Like the other strands of critical Islamic thought in Indonesia, Muslim feminism was nurtured by foreign thinkers and activists but developed into a broad-based movement - a loose coalition of women's groups and individual activists taking up various gender-related

${ }^{23}$ The first results of this project, carried out by a team of Indonesian collaborators under AnNa'im's supervision, were published as An-Na'im (2007). Similar projects were to follow in other countries. An-Na'im was already known in Indonesia for his book on the thought of Mahmoud Muhammad Taha (An-Na'im 1990), which had been translated into Indonesian and had sold surprisingly well.

${ }^{24}$ See Suminto (1989), Munhanif (1996), Effendy (1999) and Jabali and Jamhari (2002).

${ }^{25}$ I use the term 'Muslim feminism' in a broad sense that includes the whole range of Muslim women's rights activism (although many of the women concerned would reject the label 'feminist'). It subsumes Islamic feminism, which seeks to ground arguments for women's rights in Islamic scripture. 
and women's issues, both at the grassroots level and within the large associations and the state bureaucracy. Indonesian feminists have been especially successful in translating ideas into action, both at the village and small town levels and in the legislative process. They have engaged in debate with male Muslim authorities, from the national to the local levels, and they have been able to bring their concerns to the floor of Muhammadiyah and NU congresses, through the women's wings of those organizations. Their writings explore the gamut of Muslim women's issues, from reproduction, humans rights and education to inheritance laws, jurisprudence and the case for legal reform. ${ }^{26}$

In the past two decades Muslim feminism has become a global movement, with regular meetings between thinkers and activists from many countries. Within this movement, there is a broad awareness of the special significance and achievements of Indonesian women (in addition to those of Iranian women, who were the true pioneers). Unlike in most other countries, in Indonesia Muslim feminism is not an elite movement. Aided by more elite-based groups such as Malaysia's Sisters in Islam (http://www.sistersinislam.org.my/) and the transnational network Musawah (http://www.musawah.org/), whose working language is English, the Indonesian activists have grabbed international attention and are regarded as role models to be emulated. ${ }^{27}$

Like other thinkers, activists and organizers, Indonesia's Muslim feminists have never sought international attention or thought of spreading their ideas beyond the confines of their own country. It was thinkers and activists elsewhere who 'discovered' them, found their work valuable, and turned them into role models and major participants in the international networks.

\section{INDONESIA AND TURKEY COMPARED}

The reluctance of Indonesian Muslims to seek the international limelight, their modesty (or is it lack of confidence?) and their conviction that they have more to learn from than to teach others, are remarkable and become even more so when we compare them with their Turkish

\footnotetext{
${ }^{26}$ See, for example, Marcoes-Natsir and Hasyim (1997), Assegaff (2005), Marcoes-Natsir (2005), Muhammad et al. (2006) and Mulia (2004).

${ }^{27}$ Indonesian Muslim feminism has also drawn increasing scholarly attention. See, for example, Feillard (1997), Rinaldo (2008), Robinson (2008) and Brenner (2011).
} 
counterparts. In the light of Fazlur Rahman's comments on Indonesia and Turkey as the two countries offering hope for the future of an enlightened Islam, a comparison of the international impact of Muslim thought and action in these two countries may be apt. Both represent great civilizations at the edge of the Arab world, and both have developed forms of expression of Islam that are quite different from those of the Arab heartlands. Turks, however, have been much more confident than Indonesians about the value, validity and relevance to others of their Muslim culture.

Under Mustafa Kemal Atatürk (d. 1938), republican Turkey was the first Muslim state to disestablish the authority of the ulama and put in place a form of secular regime in which the state defined what proper and acceptable Islam was. Most colonized Muslim nations, including semi-colonies like Egypt, were led to independence by secular elites who adopted lighter versions of Turkish Kemalism. Meanwhile, Turkey's secular bureaucratic and military elite, which has led the country for three-quarters of a century, is being replaced by a new, socially conservative middle class steeped in Islamic piety. Not only is the ruling Justice and Development Party (AKP) held up by the United States as a shining example of how Islam and democracy may be compatible, but Islamist movements all over the world are studying the party's rise and development in the hope of emulating its successes. ${ }^{28}$ Prime Minister Erdogan and his team are very confident of the leading role their country has to play in the world of Islam.

While Sufi orders remain officially banned in Turkey, the music and dance of the Mevlevi 'Whirling Dervishes' have conquered the world, and the annual commemoration in Konya of their founder, the great poet Mevlana Jalaluddin Rumi, is an event that draws numerous pilgrims from all over the world. Turkey's most influential Muslim thinker of the twentieth century, the Kurdish mullah Bediüzzaman Said Nursi, wrote works in an archaic style that modern Turks have difficulty understanding. Risale-i Nur [Treatise on the Divine Light], a collection of his main works, is pervaded by dreams and visions, and rooted in Persian and Kurdish mystical traditions. At the same time, however, Nursi advocates modern education and the cultivation of modern science as compatible with personal piety (Mardin 1989).

\footnotetext{
${ }^{28}$ This includes Indonesia's Prosperous Justice Party (PKS) and Malaysia's Pan-Malaysian Islamic Party (PAS), both of which have - in vain - made efforts to establish closer relations with the AKP.
} 
Selections from his work have been translated into many languages and there is an active mission, the Nur movement, spreading his teachings and worldview. The Fethullah Gülen movement, which is also based on Nursi's teachings, is even more active in carrying out its Turkish-Islamic mission worldwide, establishing schools, centres of religious dialogue, charities and centres of Turkish culture in over a hundred countries worldwide, including Indonesia and Australia (Yavuz and Esposito 2003; Agai 2007; Osman 2007).

Turkish Muslims do not share the Indonesians' eagerness to learn from the Arabs; on the contrary, there is a widespread conviction that Turkish Islam is in many ways superior to the ways in which Arab Muslims practise their faith. This striking difference in attitude reflects the countries' different histories. Turkey was the heart of the Ottoman Empire, which for four centuries (1520s-1910s) ruled much of Arabia. The major centres of education, the medrese, were administered from Istanbul and their professors were appointed and paid by the central administration. There were of course autonomous centres of excellence elsewhere, such as Cairo's Al-Azhar University and the Great Mosque of Mecca, and in the late nineteenth century more private medrese emerged in Mecca offering a different curriculum. Nevertheless, most Turkish Muslim intellectuals at the time the new Turkey was established were the products of Ottoman medrese and interaction with the West, rather than of the Arab world. (Some of them went into exile in Egypt after the republic was established, but this did not contribute significantly to improving the communication of ideas.)

The history of Indonesian Muslims' connection with Arabia is a very different one. The search for wisdom, knowledge and power in hard-to-reach spiritual centres had long been a core element of Indonesian religiosity, and after the onset of Islamization Mecca replaced forest and mountain hermitages as the most prestigious centre. In the seventeenth century, several Javanese rulers sent envoys to Mecca requesting the Grand Sharif to grant them the title of sultan and spiritual endorsement of their rule. Seekers of knowledge and power travelled to Mecca to perform the hajj and stayed on for years to study Islamic law and mysticism. By the end of the nineteenth century, Southeast Asians constituted the largest immigrant community in Mecca. With only a little exaggeration one might say that the Indies had two capitals: Batavia, where the heart of Dutch commerce and administration was located, and Mecca, to which pious Muslims looked for guidance.

Under colonial rule, many pious Indonesians preferred to live in Mecca. Dutch fears of panIslamic propaganda and action from Mecca, targeting the Indies, were largely unfounded, but 
for the pious, Mecca and Arabia at large represented a free haven where religious practice was not impeded and where knowledge flourished. The pesantren, which from the nineteenth century onwards were rapidly increasing in number, could succeed only if their founders and major teachers could show that they had spent at least some years in Mecca studying under famous ulama. In the twentieth century, Cairo's Al-Azhar also attracted many Indonesian students. ${ }^{29}$ Even today, there is widespread awareness that the level of learning attained in Indonesian pesantren remains well below that offered by Al-Azhar or the Mecca-based teachers.

The history of the continuing process of Islamization of Indonesia is one of generation after generation of reformers, educated in Mecca or Cairo, returning to their homeland and 'correcting' Islamic belief and practice in accordance with what they had observed in the Middle East (Laffan 2003; Azra 2004). In the eyes of those reformers, the specifically Indonesian forms of expression that had developed were deviations needing correction. The reformist, 'Arabizing' urge was always contested and gave rise to various forms of cultural resistance, including the production of obscene Javanese texts mocking scripturalist Islam, the emergence of syncretistic esoteric (kebatinan) movements, the cultivation of nominal or less observant (abangan) culture as 'true Islam', efforts to develop an Indonesian school of Islamic law (madhhab), the advocacy of 'cultural' as opposed to 'political' Islam during the New Order period, and the rise of 'liberal Islam' and various movements supporting the use of local artistic traditions in Islamic teaching and devotions (van Bruinessen, forthcoming). All these types of resistance emphasized and celebrated local forms and expressions, and almost by definition had no ambition to be relevant to other cultural contexts.

As an afterthought, one might observe that the relations of Indian Islam with the Arab Middle East have been different from those of both Southeast Asia and the Ottoman Turks. The Muslim culture of the southern coastal regions, especially Kerala and Tamil Nadu, owes much to the Indian Ocean trade and is similar to that of Southeast Asia. All of the most prominent Indian Muslim thinkers and movements, however, hail from northern India, where Islam was established by invasion from the north. A considerable proportion of Indian Muslims are (or

\footnotetext{
${ }^{29}$ For an analysis of how Mecca and Cairo contributed to shaping Indonesia's pesantren tradition, see van Bruinessen (1994). On Indonesians in Cairo, see Abaza (1994) and Laffan
} (2003). 
believe themselves to be) the descendants of invaders, notably the nobility (ashraf), many of whom claim descent from the Prophet or his Companions. Until being replaced by Urdu in the nineteenth century, the dominant language of scholarship among Indian Muslims was Persian, and for a long time relations were closer with the Persianized regions to the north and west than with Arabia.

Indian Muslims did perform the hajj, of course, and we find Indian ulama teaching in Mecca and Medina even before the first prominent Southeast Asians arrived there. For the Indians, however, Arabia was never the sole source of Islamic learning. Following the demise of the Mughal Empire and the extension of British rule to all of India by the mid-nineteenth century, some ulama opted for exile in Mecca, like their Indonesian counterparts. The most illustrious of the Indian ulama, Rahmat Allah Kairanawi, established Mecca's first modern madrasah, the Sawlatiyya, which attracted Indonesian as well as Indian students. In the long term, however, it proved to be more significant for Indonesian than for Indian Islam. It was the madrasah of Deoband in north India rather than any Meccan institution that contributed most to shaping contemporary Indian Islam. ${ }^{30}$

\section{INDONESIA AS A MARKET AND NEW HOME BASE FOR MOVEMENTS ORIGINATING ELSEWHERE}

Indonesian Islam may not (yet) be 'export oriented', but a wide range of Islamic movements views Indonesia as a huge and attractive market, and carries out active missions there. As observed above, Natsir's DDII was actively supported by Saudi Arabia and the Muslim World League in bringing Indonesian belief and practice into greater conformity with those on the Arabian Peninsula. Both the Muslim Brotherhood and, later, the Salafi movement gained their first foothold in Indonesia through the good offices of the DDII (van Bruinessen 2002).

After the Iranian revolution, many young Indonesians converted from Sunni to Shi'a Islam. This movement was self-generated, and the Iranian Embassy was reluctant to be seen supporting it. However, it quickly met a massive counter-offensive from Saudi Arabia and other Gulf countries, which felt threatened by Iran's revolutionary rhetoric. Initially they used

\footnotetext{
${ }^{30}$ On Rahmat Allah Kairanawi and other Indian ulama and the role of Mecca, see Alavi (2011). On the significance of the Sawlatiyya for Indonesian Islam, see van Bruinessen (1994). On Deoband and its significance for Indian Islam, see Metcalf (1978).
} 
Natsir and the DDII as their vehicles, but soon these were circumvented by Saudi-controlled institutions in Jakarta, such as the Institute for Arabic and Islamic Studies (LIPIA) and the Muslim World League. Indonesia's Salafi movement, the most recent and dynamic of its various Islamic movements, is actively supported and supervised by foundations and individuals in Saudi Arabia, Kuwait, Yemen and Qatar (Hasan 2006, 2010).

The Indonesian chapter of Hizb ut-Tahrir, Hizbut Tahrir Indonesia (HTI), may have emerged more or less accidentally after its chief organizer was invited to leave Australia to teach Arabic in a pesantren in Bogor. Its spectacular growth and great visibility since 1998 have made HTI the strongest 'national' chapter of this anti-nationalist, avowedly global caliphate movement (Osman 2009, 2010). Indonesia is, moreover, one of the few Muslim countries where the organization is not banned, making it of crucial importance to the central leadership. Given the strong Arab bias in the movement, in spite of its global pretensions, it is unlikely that Indonesians will come to lead it any time soon, or that the movement will adapt itself to Indonesian peculiarities. However, this is probably the first transnational Muslim movement that has had to take serious account of its Indonesian followers.

A transnational movement of a very different kind, for which Indonesia has also become increasingly important, is the Naqshbandiyya Haqqaniyya Sufi order. Its charismatic grand sheikh, Nazim al-Qubrusi, was born in the Turkish part of Cyprus (where he has now retired), but the order has become truly global, with branches in many Muslim countries and converts across Europe and North America. The current de facto leader is the grand sheikh's representative in North America, Hisham Kabbani, who among other things has made the order the central pillar of a worldwide anti-fundamentalist alliance. In the 1990s, Sheikh Nazim and Sheikh Hisham began directing their activities towards Southeast Asia, in what was seen by some as an effort to find a permanent base in a major Muslim region. In the 2000s the latter has made annual visits to Indonesia, establishing connections with existing Sufi networks and founding branches of Haqqaniyya among the urban middle class. The Indonesian connection is now of central importance to the order (Laffan 2006: Nielsen, Draper and Yemelianova 2006).

Other transnational movements that have recently intensified their activities in Indonesia include Tablighi Jama' at and the Fethullah Gülen movement. Both initially restricted their international expansions to culturally related populations (the South Asian diaspora in the case of the former and the Turkish diaspora and Turkic peoples of Central Asia in the case of 
the latter) but in the past decade have succeeded in making major inroads among non-related populations. Indonesia is a significant, though not the most important, field of mission for them. Their activities have, however, contributed to the increased visibility of Indonesians among Muslim populations elsewhere.

\section{CONCLUSION}

Indonesia has not regained the leading position it held briefly among Muslim nations in the 1950s, but its visibility has increased significantly since the fall of the Suharto regime, and there is a new confidence among Indonesian leaders to take initiatives in the international arena. The role of Indonesia in such international Muslim forums as the Organization of the Islamic Conference has not been remarkable so far, and its efforts to mediate in international conflicts (the southern Philippines, the Middle East) have been relatively modest, but at least the government has been positioning itself for a new international role in the Muslim arena (Perwita 2007). NU's first major international initiative, the International Conference of Islamic Scholars, may have had more to do with Hasyim Muzadi's bid for the vice-presidency than with the association's international ambitions, but NU has continued to project itself in the international arena. Indonesia's growing confidence is also evident in the increased charitable activity directed towards Palestine, in which several Indonesian Muslim charities have been competing for attention (Latief 2009; Latief, forthcoming).

The increased visibility of the Indonesian ummah has drawn a broad range of transnational Muslim movements to the country, for some of which Indonesia appears to be becoming the most important field of action. In this sense, too, the Indonesian ummah may be seen to be moving from a peripheral to a more central position, corresponding to its demographic weight.

Indonesian Islam is characterized by a vibrant intellectual discourse, a remarkable openness to alternative views and a broad acceptance of religious pluralism, in spite of a strong anti-liberal and anti-pluralist reaction during the past six or seven years. Although the uniqueness and attractiveness of Indonesia's Muslim intellectualism have been noticed by visiting foreign Muslims, its impact beyond Indonesia has been minimal, especially when compared with that of other major cultural regions such as Turkey and South Asia. Indonesia's Muslim thinkers

have been eager to draw inspiration from a wide variety of sources, many of them foreign, but they have remained remarkably reluctant to disseminate their own work abroad. 
Part of the explanation for the lack of international impact of Indonesian Muslim thought, as suggested above, lies in the fact that most Indonesian Muslim thinkers have been activists whose writing has served a social or political purpose. They have not written great synthesizing works but rather numerous shorter pieces, often in response to questions or circumstances that may not immediately make sense to foreign audiences, even if inspired by universal ideas. The thrust of much of their discourse concerns the defence of pluralism, variety and local colour in the cultural expressions of Islam, against the homogenizing tendencies of transnational Islamism. It is perhaps too inherently local to be exportable. 


\section{REFERENCES}

Abaza, Mona (1994) Indonesian Students in Cairo: Islamic Education, Perceptions and Exchanges, Association Archipel, Paris.

Abaza, Mona (2007) 'More on the shifting worlds of Islam. The Middle East and Southeast Asia: a troubled relationship?', Muslim World 97(3): 419-36.

Abaza, Mona (2011) 'Asia imagined by the Arabs', in K. Bustamam-Ahmad and P. Jory (eds) Islamic Studies and Islamic Education in Contemporary Southeast Asia, Yayasan Ilmuwan, Kuala Lumpur.

Agai, Bekim (2007) Zwischen Netzwerk und Diskurs: Das Bildungsnetzwerk um Fethullah Gülen (geb. 1938): Die Flexible Umsetzung Modernen Islamischen Gedankengutes [Between Network and Discourse: The Educational Network around Fethullah Gülen (b. 1938): The Flexible Transformation of Modern Islamic Thought], EB-Verlag, Berlin.

Al-Andunisi, Abu Hilal (1984) Ghara Tabshiriyya Jadida 'ala Andunisya [The New Missionary Invasion of Indonesia], Dar al-Shuruq, Jeddah.

Alavi, Seema (2011) “Fugitive mullahs and outlawed fanatics": Indian Muslims in nineteenth century trans-Asiatic imperial rivalries', Modern Asian Studies 45(6): 1,337-82.

An-Na'im, Abdullahi Ahmed (1990) Toward an Islamic Reformation, Syracuse University Press, New York NY. (Published in Indonesian in 1994 as Dekonstruksi Syari'ah: Wacana Kebebasan Sipil, Hak Asasi Manusia dan Hubungan Internasional dalam Islam

[Deconstructing the Shariah: The Discourse of Civil Liberties, Human Rights and International Law in Islam], LKiS, Yogyakarta.)

An-Na'im, Abdullahi Ahmed (2007) Islam dan Negara Sekuler: Menegosiasikan Masa Depan Syariah [Islam and the Secular State: Negotiating the Future of the Shariah], Mizan, Bandung.

Assegaff, Farha Abdul Kadir (2005) 'Islamist feminism? Syariah for the empowerment of women: the case of Indonesia's Pesantren Al-Firdaus', Islam, Syari'ah and Governance Background Paper No. 5, Melbourne Law School, University of Melbourne, Melbourne. 
Azra, Azyumardi (2004) The Origins of Islamic Reform in Southeast Asia: Networks of Malay-Indonesian and Middle Eastern 'Ulama' in the Seventeenth and Eighteenth Centuries, KITLV Press, Leiden.

Barton, Gregory James (1995) 'The emergence of neo-modernism: a progressive, liberal movement of Islamic thought in Indonesia. A textual study examining the writings of Nurcholish Madjid, Djohan Effendi, Ahmad Wahib and Abdurrahman Wahid, 1968-1980', $\mathrm{PhD}$ thesis, Monash University, Clayton.

Bradley, Francis R. (2010) 'The social dynamics of Islamic revivalism in Southeast Asia: the rise of the Patani school', PhD dissertation, University of Wisconsin, Madison WI.

Brenner, Suzanne (2011) 'Private moralities in the public sphere: democratization, Islam, and gender in Indonesia', American Anthropologist 113(3): 478-90.

Dahlan, Ihsan M. (n.d.) Siraj al-Talibin, Sharh 'ala Minhaj al- 'Abidin [Guidance for Seekers, a Commentary on the Path of Worshippers], al-Haramayn, Jeddah.

Effendy, Edy A. (ed.) (1999) Dekonstruksi Islam: Mazhab Ciputat [Deconstructing Islam: The School of Ciputat], Zaman Wacana Mulia, Bandung.

Feener, R. Michael and Michael F. Laffan (2005) 'Sufi scents across the Indian Ocean: Yemeni hagiography and the earliest history of Southeast Asian Islam', Archipel 70: 185208.

Feillard, Andrée (1997) 'Indonesia’s emerging Muslim feminism: women leaders on equality, inheritance and other gender issues', Studia Islamika 4(1): 83-111.

Göksoy, Ismail Hakki (1995) Endonezya’da Islam ve Hollanda Sömürgeciligi [Islam in Indonesia and Dutch Colonialism], ISAM Yayinlari, Ankara.

Hasan, Noorhaidi (2006) Laskar Jihad: Islam, Militancy and the Quest for Identity in PostNew Order Indonesia, Cornell Southeast Asia Program, Ithaca NY.

Hasan, Noorhaidi (2010) 'The failure of the Wahhabi campaign: transnational Islam and the Salafi madrasa in post-9/11 Indonesia', South East Asia Research 18(4): 675-705. 
Hassan, Riffat (1990) 'Teologi perempuan dalam tradisi Islam: sejajar di hapadan Allah' [The theology of women in Islamic tradition: equal before God], 'Ulumul Qur'an: Jurnal Ilmu dan Kebudayaan 1(4): 48-55.

Heiss, Johann and Martin Slama (2010) 'Genealogical avenues, long-distance flows and social hierarchy: Hadrami migrants in the Indonesian diaspora', Anthropology of the Middle East 5(1): 34-52.

Ho, Engseng (2006) The Graves of Tarim: Genealogy and Mobility across the Indian Ocean, University of California Press, Berkeley CA.

Jabali, Fuad and Jamhari (2002) IAIN dan Modernisasi Islam di Indonesia [The IAIN and the Modernization of Islam in Indonesia], Logos, Jakarta.

Kostiner, Joseph (1984) 'The impact of the Hadrami emigrants in the East Indies on Islamic modernism and social change in the Hadramawt during the 20th century', in R.I. and A.H. Johns (eds) Islam in Asia. Volume 2: Southeast and East Asia, Westview Press, Boulder CO.

Kuntowijoyo (2001) Muslim Tanpa Masjid: Esai-esai Agama, Budaya, dan Politik dalam Bingkai Strukturalisme Transendental [Muslims without Mosques: Essays on Religion, Culture and Politics in the Framework of Transcendental Structuralism], Mizan, Bandung.

Laffan, Michael F. (2003) Islamic Nationhood and Colonial Indonesia: The Umma below the Winds, RoutledgeCurzon, London.

Laffan, Michael F. (2006) 'From alternative medicine to national cure: another voice for the Sûfî orders in the Indonesian media', Archives de Sciences Sociales des Religions 135: 91115.

Latief, Hilman (2009) 'Internationalising domestic aid: charity activism and Islamic solidarity movement in contemporary Indonesia', paper presented at the International Graduate Student Conference, Gadjah Mada University, Yogyakarta, 23 November.

Latief, Hilman (forthcoming) 'Islamic charities and social activism: welfare, $d a$ ' $w a$ and politics', PhD dissertation, Utrecht University, Utrecht.

Mackie, Jamie (2005) Bandung 1955: Non-alignment and Afro-Asian Solidarity, Didier Millet, Singapore. 
Madjid, Nurcholish (1987) Islam, Kemodernan dan Keindonesiaan [Islam, Modernity and Indonesian-ness], Bandung: Mizan.

Madjid, Nurcholish and Mohamad Roem (2000) Tidak ada Negara Islam: Surat-surat Politik Nurcholish Madjid - Mohamad Roem [The Islamic State Does Not Exist: Political Correspondence of Nurcholish Madjid and Mohamad Roem], Djambatan, Jakarta.

Marcoes-Natsir, Lies (2005) 'Abortion and the Qur'an: a need for reinterpretation in Indonesia?', in A. Saeed (ed.) Approaches to the Qur'an in Contemporary Indonesia, Oxford University Press, Oxford.

Marcoes-Natsir, Lies and Syafiq Hasyim (1997) P3M dan Program Fiqh an-Nisa untuk Penguatan Hak-hak Reproduksi Perempuan [P3M and a Program of Women's Fiqh for Strengthening Women's Reproductive Rights], P3M, Jakarta.

Mardin, Serif (1989) Religion and Social Change in Modern Turkey: The Case of Bediuzzaman Said Nursi, State University of New York Press, Albany NY.

Metcalf, Barbara D. (1978) 'The madrasah at Deoband: a model for religious education in modern India', Modern Asian Studies 12: 111-34.

Mobini-Kesheh, Natalie (1999) The Hadrami Awakening: Community and Identity in the Netherlands East Indies, 1900-1942, Cornell Southeast Asia Program, Ithaca NY.

Muhammad, K.H. Husein et al. (2006) Dawrah Fiqh concerning Women: Manual for a Course on Islam and Gender, Fahmina Institute, Cirebon.

Mujiburrahman (2006) Feeling Threatened: Muslim-Christian Relations in Indonesia's New Order, Amsterdam University Press, Amsterdam, available at http://igiturarchive.library.uu.nl/dissertations/2006-0915-201013/.

Mulia, Siti Musdah (2004) 'Modernisation of Islamic law. Counter legal draft: the compilation of Indonesian Islamic law', Gender Mainstreaming Team, Ministry of Religious Affairs, Jakarta.

Munhanif, Ali (1996) 'Islam and the struggle for religious pluralism in Indonesia: a political reading of the religious thought of Mukti Ali', Studia Islamika 3(1): 79-126.

Natsir, Mohamad (1955) Capita Selecta [Selected Writings], Jakarta: Bulan Bintang. 
Nielsen, Jørgen S., Mustafa Draper and Galina M. Yemelianova (2006) 'Transnational

Sufism: the Haqqaniyya', in J. Malik and J. Hinnells (eds) Sufism in the West, Routledge, London.

Osman, Mohamed Nawab (2007) 'Gülen's contribution to a middle way Islam in Southeast Asia', paper presented at a conference on the Muslim World in Transition: Contributions of the Gülen Movement, London School of Economics, London, 25-27 October, available at http://www.fethullahgulen.org/conference-papers/302-contributions-of-the-gulen$\underline{\text { movement/2465-gulens-contribution-to-a-middle-way-islam-in-southeast-asia.html. }}$

Osman, Mohamed Nawab (2009) 'Reviving the caliphate in the Nusantara: Hizbut Tahrir Indonesia's mobilization strategy and its impact in Indonesia', RSIS Working Paper No. 171, S. Rajaratnam School of International Studies, Singapore, February, available at http://www.rsis.edu.sg/publications/WorkingPapers/WP171.pdf.

Osman, Mohamed Nawab (2010) 'The transnational network of Hizbut Tahrir Indonesia', South East Asia Research 18(4): 735-56.

Perwita, Anak Agung Banyu (2007) Indonesia and the Muslim World: Islam and Secularism in the Foreign Policy of Soeharto and Beyond, NIAS Press, Copenhagen.

Pijper, G.F. (1977) Studiën over de Geschiedenis van de Islam in Indonesië 1900-1950 [Studies on the History of Islam in Indonesia, 1900-1950], Brill, Leiden.

Rakhmat, Jalaluddin (1986) Islam Alternatif: Ceramah-ceramah di Kampus [Alternative Islam: Campus Lectures], Mizan, London and Bandung.

Rinaldo, Rachel (2008) 'Envisioning the nation: women activists, religion and the public sphere in Indonesia', Social Forces 86(4): 1,781-804.

Robinson, Kathryn (2008) 'Islamic cosmopolitics, human rights, and anti-violence strategies in Indonesia', in P. Werbner (ed.) Anthropology and the New Cosmopolitanism, Berg, Oxford.

Salim, H. Agus (1954) Djedjak Langkah Hadji A. Salim: Pilihan Karangan, Utjapan dan Pendapat Beliau dari Dulu sampai Sekarang [In the Footsteps of Haji A. Salim: Selected Writings, Lectures and Opinions of a Lifetime], Tintamas, Jakarta.

Schulze, Reinhard (1983) 'Der einfluss Islamischer organisationen auf die länder Südostasiens - von Mekka aus gesehen' [The influence of Islamic organizations on the 
countries of Southeast Asia, seen from Mecca], in W. Draguhn (ed.) Der Einfluss des Islams auf Politik, Wirtschaft und Gesellschaft Südostasiens [The Influence of Islam on the Politics, Economy and Society of Southeast Asia], Institut für Asienkunde, Hamburg.

Schulze, Reinhard (1990) Islamischer Internationalismus im 20: Jahrhundert.

Untersuchungen zur Geschichte der Islamischen Weltliga [Islamic Internationalism in the 20th Century: Studies on the History of the Muslim World League], Brill, Leiden.

Shalabi, Ahmad (1983) The Encyclopaedia of Islamic History: Islam and Non-Arabicspeaking Muslim Countries, Maktabat al-Nahda al-Misriyya, Cairo.

Suminto, H. Aqib (ed.) (1989) Refleksi Pembaharuan Pemikiran Islam: 70 Tahun Harun Nasution [Reflections on the Renewal of Islamic Thought on the Occasion of Harun Nasution's 70th Birthday], Lembaga Studi Agama dan Filsafat, Jakarta.

van Bruinessen, Martin (1990) 'Kitab kuning: books in Arabic script used in the pesantren milieu', Bijdragen tot de Taal-, Land-en Volkenkunde 146: 226-69.

van Bruinessen, Martin (1994) 'Pesantren and kitab kuning: continuity and change in a tradition of religious learning', in W. Marschall (ed.) Texts from the Islands: Oral and Written Traditions of Indonesia and the Malay World, University of Berne Institute of Ethnology, Berne.

van Bruinessen, Martin (2002) 'Genealogies of Islamic radicalism in Indonesia', South East Asia Research 10(2): 117-54.

van Bruinessen, Martin (2011) 'What happened to the smiling face of Indonesian Islam? Muslim intellectualism and the conservative turn in post-Suharto Indonesia', RSIS Working Paper No. 222, S. Rajaratnam School of International Studies, Singapore, 6 January, available at http://www.rsis.edu.sg/publications/workingpapers/wp222.pdf.

van Bruinessen, Martin (forthcoming) 'Ghazwul fikri or Arabization? Indonesian Muslim responses to globalization', in K. Miichi (ed.) Muslim Responses to Islam and Globalization in Southeast Asia.

Wahid, Abdurrahman (2006) Islamku, Islam Anda, Islam Kita: Agama Masyarakat Negara Demokrasi [My Islam, Your Islam, Our Islam: Religion, Society, State and Democracy], Wahid Institute, Jakarta. 
Yavuz, M. Hakan and John L. Esposito (eds) (2003) Turkish Islam and the Secular State: The Gülen Movement, Syracuse University Press, New York NY. 


\section{GLOSSARY}

abangan

AKP

Al-Irsyad

DDII

HTI

IAIN

kiai

LIPIA

madhhab

madrasah

Masyumi

Muhammadiyah

NGO

NU

Pancasila nominal or less strict Muslims

Adalet ve Kalkinma Partisi (Justice and Development Party) (Turkey)

Jam'iyah al-Islah wa al-Irsyad (Union for Reformation and Guidance), founded 1913

Dewan Dakwah Islamiyah Indonesia (Indonesian Council for Islamic Propagation), founded 1967

Hizbut Tahrir Indonesia (Indonesian Liberation Party), the Indonesian chapter of Hizb ut-Tahrir

Institut Agama Islam Negeri (State Islamic Institute)

title of a religious scholar or leader

Lembaga Ilmu Pengetahuan Islam dan Arab (Institute for Arabic and Islamic Studies), founded 1980

school of Islamic law

Islamic school or college

Majelis Syuro Muslimin Indonesia (Indonesian Muslim

Consultative Council), founded under the Japanese in 1943,

became a political party in 1945, banned by Sukarno in 1960

modernist Islamic organization, founded 1912

non-government organization

Nahdlatul Ulama, traditionalist Islamic organization, founded 1926

the five guiding principles of the Indonesian state, namely belief in God, humanitarianism, national unity, democracy and social justice 
PAS

pembaruan

Persis

pesantren

PKS

Salafism

Sayyid

Shia

Sufism

Sunni

tafsir

ulama

ummah
Parti Se-Islam Malaysia (Pan-Malaysian Islamic Party)

reform, renewal

Persatuan Islam (Islamic Association), reformist Islamic organization, founded 1923

traditional Islamic boarding school

Partai Keadilan Sejahtera (Prosperous Justice Party)

term used to describe movements that seek to return to the teachings and example of the early generations of Muslims; usually refers to the most strictly puritanical of these movements title of descendants of the Prophet Mohammad second-largest branch of Islam (after Sunni)

Islamic mysticism

majority branch of Islam

exegesis, particularly of the Qur'an

Islamic scholar

the Islamic community 